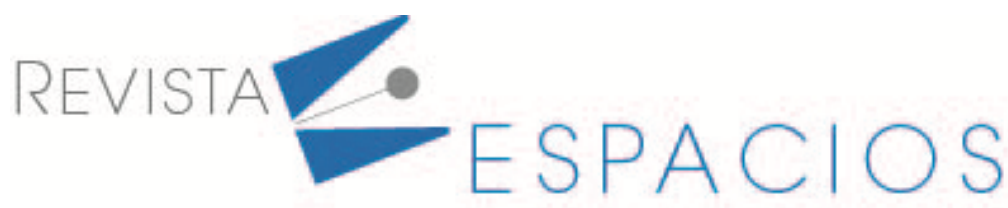

\title{
Instagram as a value co-creation tool for the image of tourist destination. Analysis of the case of Spain during Covid-19: the Balearic and the Canary islands
}

\author{
Instagram como herramienta de co-creación de valor para los destinos turísticos. Análisis \\ del caso de España durante el covid-19: las Islas Canarias y Baleares
}

\author{
ANTOLÍN-PRIETO, Rebeca ${ }^{1}$ \\ SARMIENTO-GUEDE, José Ramón ${ }^{2}$ \\ ANTONOVICA, Arta $^{3}$
}

\begin{abstract}
The main aim of this paper is to see, whether a theoretical model on tourism image management applied through the social media platform Instagram, can analyze image affected by Covid-19 pandemic. This paper presents research of the cases of the Balearic and Canary Islands. The methodology is based on content analysis that studies use of hashtags and visual materials. Results confirm that it is crucial to follow up Instagram on the current situation, as it gives credibility in terms of a "safe destination".

Key words: tourism destination, user-generated content (UGC), destination management organisation (DMO).

\section{Resumen}

El objetivo principal de este estudio es constatar si un modelo teórico sobre la gestión de la imagen turística aplicado a través de la red social Instagram permite analizar el impacto de la pandemia covid19. Este artículo presenta una investigación de las Islas Baleares y Canarias. La metodología se basa en el análisis de contenido que estudia el uso de hashtags y materiales visuales. Los resultados confirman que es fundamental hacer un seguimiento de la imagen turística a través de Instagram, ya que aporta credibilidad en términos de un "destino seguro".

Palabras clave: destino turístico, contenido generado por el usuario (UGC), organización de gestión del destino (DMO).
\end{abstract}

\section{Introduction}

According to the World Tourism Organization, the growth forecasts made in the tourism sector for Spain in 2020 were 4\% (Ministerio de Industria, Comercio y Turismo, 2020). But this projection disappeared when the World Health Organization declared the SARS CoV-2 virus as the origin of a global pandemic.

\footnotetext{
${ }^{1}$ Marketing Professor. Department of Business Economics. Rey Juan Carlos University. Spain. Contact e-mail: rebeca.antolin@urjc.es

${ }^{2}$ Marketing Professor. Department of Business Economics. Rey Juan Carlos University. Spain. Contact e-mail: joseramon.sarmiento@urjc.es

${ }^{3}$ Marketing Professor. Department of Business Economics. Rey Juan Carlos University. Spain. Contact e-mail: arta.antonovica@urjc.es
} 
In this context of uncertainty, tourist destination management organizations (DMOs) faced new challenges and had to concentrate all their efforts on transmitting the brand image through the co-creation of value with their target audience, taken in account that their opinions, comments and a prosumer role is essential in this new situation. Thus, the brand image of a tourist destination appears as an important element: for transmitting values and generating trust (Sarmiento y Ferrao, 2019). Hence, González (2012) has already stated that, in situations of economic or health crisis, tourist DMOs had to be able to transmit their divergence and their value through the brand, otherwise, it means that the brand does not add any difference in values.

The brand image of a tourist destination can be created through the non-traditional media, that is through unofficial communication tools such as word-of-mouth or user-generated content in the social media. Therefore, according to Bigné (2018), the co-creation of brand value by consumers through social media is determinant. Also, Brey (2019) affirms that via social media, organizations influence customers while supporting value cocreation for the brand and users simultaneously.

Statista (published by Tankovska, 2021), the official website of the worldwide online users and their behaviour at beginning of the 2021 in its report entitled "Global social networks ranked by number of users 2021", shows the following data about the users of the online platforms: Facebook has 2.7 billions, YouTube has 2 billions, WhatsApp 2 billions, Facebook Messenger 1.3 billions, Instagram 1.1 billions, and TikTok 689 millions. In this sense, in the tourism industry the social media platforms such as Facebook, Twitter and Instagram are the best social media channels, but each of the platform has its strategic objectives and specific activities. Hence, Facebook is used to attract users between different social groups and create a space for recommendations that allow to share experiences of its users. Twitter is useful for customer service and for engaging in conversations, while Instagram is the best of the three social networks for its emphasis on visual appeal materials, which makes it the most effective tool for the co-creation of tourist destination image (Sarmiento and Rodríguez, 2020).That is why in this research paper, we will focus on the social media of Instagram. As it is the communication tool that has grown the most in recent years and, hence, the most used in the tourism sector (Sarmiento and Ferrao, 2019).

In recent years social media and UGC have become an object of study for many academics (Sarmiento and Ferrao, 2019). However, the questions of how and to what extent tourist DMOs can use social media and in particular Instagram as a tool for co-creation of brand value, have not yet been addressed by researchers, for the improvement of image in situations of economic or health crisis. This lack of studies is what justifies our research (Iglesias-Sánchez et al, 2020).

\section{Literature review}

\subsection{The image of the tourist destination through Instagram}

The term tourist destination image was defined by Hunt in 1975 and he identified it as the perceptions that potential tourists have about a specific area (Hunt, 1975). For the image of a tourist destination to be effective, attributes that satisfy the needs of tourists must be selected, in order to differentiate the destination compared to its competitors (García Haro, 2018). Specifically, the image of the destination has two main functions in consumer behaviour: (1) to influence the decision-making process of tourists, and (2) to have an impact on their intention to visit or recommend the tourist destination again (Bigné et al, 2005).

In the past travel agents and intermediaries were considered as an extremely important source of information for the development of the image of a tourist destination, but today with the arrival of the Internet and the emergence of the media social, these agents have lost weight in the influence of the image of a tourist destination (Frías et al, 2017). And, thus, social media have become a source of information that allows the exchange of 
tourists' perceptions and today constitute a new fundamental communication and marketing tool for the tourism sector (Költringer and Dickinger, 2015).

Furthermore, changes brought by social media in the tourism sector are forcing tourism DMOs to implement social media as a tool to improve communication with the costumers and to satisfy their needs. However, Iglesias-Sánchez et al (2020) state that currently "the scope of social media used by tourist DMOs are taking advantage of their true potential to promote the image of a tourist destination".

It is known that tourist DMOs have traditionally endeavoured to create the brand image in order to influence tourists. However, with the emergence of social media the brand image of a tourist destination is built through UGC and by DMOs (Munar, 2011). Therefore, co-creation through social media contributes to the development of the image of a tourist destination.

There are some research papers that have already highlighted the importance of social media in promoting a tourist destination (Hanan and Putit, 2014; Sarmiento-Guede et al., 2021). However, most of them have only been limited to applying them in social media channels such as TripAdvisor, Facebook, or blogs (Iglesias-Sánchez et al, 2020).

In sum, in the published literature there is still a lack of studies devoted to examining, what influence on the image of a destination the content generated by Instagram users can have or to describe how tourist DMOs can use the tool. In this context, we propose the following research question (RQ):

RQ1. How do destination management organizations project the image of a tourist destination through Instagram?

\subsection{Co-creation of the image of the tourist destination through Instagram}

The co-creation of value was defined by Grönroos (2020), as the joint creation of value during the interaction process between the organization and customers. In this sense, the customer not only determines value, but is also the value creator (Grönroos, 2017).

In recent years, Instagram is the social media platform that has grown the most in number of users. Millions of images are uploaded every day that receive billions of likes from more than 800 million registered users (Araújo, 2019). The platform reports images to a universal size and can be edited. Thus, the user can tag other users in the images, tag the place where the photograph has been captured, and write a title for the image that is included through hashtags and put mentions (marked with \# and @, respectively) to share the image and categorize the content (Walter and Giolgio, 2014). Thus, all the content generated on Instagram has become a source of information and creation of travel experiences, which makes Instagram "an ideal tool to build the image of a tourist destination" (Hanan and Putit, 2014) and the co-creation of value (Ramaswamy, 2009).

Today DMOs are already aware of the role that users play on social media. However, the correct understanding of why tourists are motivated to generate valuable content and to promote the attractiveness of a destination requires a broader and more detailed analysis. Thus, we present the following research question:

RQ2. How do users participate in the creation of the brand image of a tourist destination?

In the literature reviewe it is found that social media has become an indispensable tool for image co-creation, because it allows tourists to interact and communicate better and because it facilitates for the tourist DMOs to create closer relationships with them (Law et al, 2014). Currently, experiences are considered by many authors as the core of the tourism industry and as a source of value creation (Sorensen et al, 2017). 
The co-creation of the image of a tourist destination requires that the UGC matches to the content generated by the tourism DMOs, otherwise there will not be value creation. Hence, Hanan and Putit (2014) consider "the Instagram platform as a strategic tool for communication in the tourism sector and, consequently, conclude that the tourism DMOs should not miss the opportunity to use it and take advantage of the content generated by users".

Thanks to social media and particularly to Instagram, the brand image of a tourist destination is the result of created photographs, the videos and user reviews. However, it is necessary to carry out a comparative analysis between the destination image created by users and those generated by the tourism DMOs. Consequently, we propose the third research question:

RQ3. To what extent do the images generated by tourist destination management organizations correspond to those generated by users?

\subsection{The use of social media in Spain during Covid-19 to co-create brand value}

Aware of the importance of the Internet and especially social media as a communication tool, some official tourist institutions in Spain have developed communication campaigns during Covid-19 pandemic to co-create a brand value. Turespaña in 2020, a body of the Ministry of Industry, Commerce and Tourism (2020), has launched the campaign under the slogan "Spain awaits you" with an emotional ad recommending staying at home, although remember that Spain is still a very popular tourist destination. Hence, most of the autonomous communities of Spain were carrying out communication campaigns to interact with tourists and co-create content about the most relevant tourist attractions in each region during this sanitary crisis. Among them, Andalusia stands out with the motto "Andalusia wants you at home"; Mallorca, with \#SeeYouSoonMallorca; or Valencia, with \#DreamTheMediterraneanLive. At the international level we can mention the campaign created by the World Tourism Organization (UNWTO) with the slogan \#Travel Tomorrow.

Therefore, communication is always necessary, but in times of crisis and pandemics it is essential. The co-creation of content and the use of social media can maintain and enhance the image. Currently, users have been very active and participative in the social media of the tourism sector by generating content to co-create the image of the destination or co-creating value of the lived tourism experiences. In this sense, we offer the fourth research question:

RQ4. Is Instagram an ideal tool to co-create the image of a tourist destination during Covid-19 pandemic?

\section{Methodology}

For this research project, the authors have decided to use a qualitative research technique: a content analysis for the social media platform Instagram. In this sense, content analysis is a set of methods for analyzing the symbolic content of any communication (Singleton and Bruce, 2010: 420). Among the forms suitable for study are books, magazines, web pages, postings on the Internet, and other recorded human communications (Babbie, 2014). Therefore, this technique now is playing an increasingly important role in leisure and tourism research (Veal, 1997: 141). To make this decision on the methodology, we follow the case study of social media marketing of the tourism sector carried out by Park and Oh (2012), and for evaluation of social media posts, photos and latent content in Instagram users' messages examination, we have used content analysis (Weber, 1990; Kim and Stepchenkova, 2015), as well as comparative metrics between tourist destination accounts: the Canary Islands (@islascanariasoficial) and the Balearic Islands (@turismoislasbaleares). In addition, we have added the analysis of the most popular hashtags related to both destinations in the Canary Islands and the Balearic Islands. For our study it was necessary to get a panoramic view and qualitative analysis to understand the co-creation of value. 
Therefore, we had to observe and analyze the contents of the community managers of the DMOs and Instagram users.

According to the research questions proposed previously in this study, the image of tourist destinations, in particularly the cases of the Canary Islands and the Balearic Islands, are analyzed from two different, but complementary points of view in order to understand the co-creation of value: the content generated by the DMO and the UGC on Instagram.

Design procedure of the applied content analysis for this research paper, was based on the investigations of several authors (Nixon et al., 2017; Iglesias-Sánchez et al., 2020). For approaching Instagram analytically, it is required a different tactic of measurement, because the nature of this social media platform is interactive and experience based, especially if we consider the use of mobile app to take the photos and add a phrase with hashtags, comments, or likes, etc. That is why the content categories have been based on indicators and variables validated by those previous studies that helps us to understand better the co-creation of the image of the tourist destinations of the tourism DMOs in the Canary Islands and the Balearic Islands, with users-generated content in the same destinations.

After a detailed analysis of each post of the studied Instagram accounts (@islascanariasoficial and @turismoislasbaleares), decisions were made on the metrics that were subsequently developed, since quantitative approach was needed to be included in this study in order to acquire more holistic vision of content generation management for the image co-creation of tourist destinations by the DMO and the users (understood as UGC) of Instagram. Hence, there have been used "Socialbakers" tool to monitor the official Instagram accounts and look for the Instagram management patterns for both destinations. The main idea was to understand the traffic of user activity, such as the division of posts according to the photos or videos with their comments, likes, views, and taking in account the classification and established categories (coast, landscape, cities \& attractions, culinary, experiences, promotional).

Thus, for measuring the posts popularity and volume (whether photos or videos) of Instagram users (UGC) were applied a "Hashtracking" tool and, in addition, we confronted it with the results obtained with "Tweetbinder" software. In Table 1 we can see the hashtags that were monitored and that correspond to the name of the social account of the studied DMOs (\#islascanariasoficial and \#turismoislasbaleares). Also, the investigated hashtags included words that were directly related to the destinations of the Canary and the Balearic Islands: \#islascanarias, \#canaryislands, \#islasbaleares and \#balearicislands.

Table 1

Monitored hashtags (July-August 2020)

\begin{tabular}{|c|c|c|c|}
\hline The Canary Islands & Instances of use & The Balearic Islands & Instances of use \\
\hline \# islascanariasoficial & 116,772 & \#turismoislasbaleares & 11,093 \\
\hline \#islascanarias & $2,283,599$ & \#islasbaleares & 622,279 \\
\hline \#canaryislands & $3,571,595$ & \#balearicislands & 456,794 \\
\hline
\end{tabular}

Source: own elaboration

As for data collection, in the case of the contents of the Instagram profiles of the official DMOs, @islascanariasoficial and @turismoislasbaleares, all the posts published from both accounts were analyzed, photos and videos, as well as the written content and linked comments. The total sample was 79 posts: 28 from the Canary Islands and 51 from the Balearic Islands. The choice of the sample size was based on the study done by Iglesias-Sanchez, et al. (2020). On the other hand, a sample posts published on Instagram by UGC were studied under the following hashtags: for the Canary Islands \# Islascanariasoficial, \#islascanarias, \#canaryislands and for the Balearic Islands \#turismoislasbaleares, \#islasbaleares and \#balearicislands. Also, a representative number of 
images were used. Thus, it was decided that one of the last five entries with more than 10 comments would be chosen. Finally, a random sample of 126 photographs from each destination was determined.

Therefore, content analysis on the Instagram platform (created by the DMOs, as well as UGC) were carried out with the tools explained previously between July 1 to August 31, 2020. The monitoring process was applied at the same time for both destinations taking into account that in the summer time tourism related activities are growing also on social media, and hence, it is rising the co-creation of value of the said tourist destinations. Although unlike other years, this studied year 2020 was under the COVID-19. The applied research phases are shown in Figure 1.

Figure 1

Research phases followed

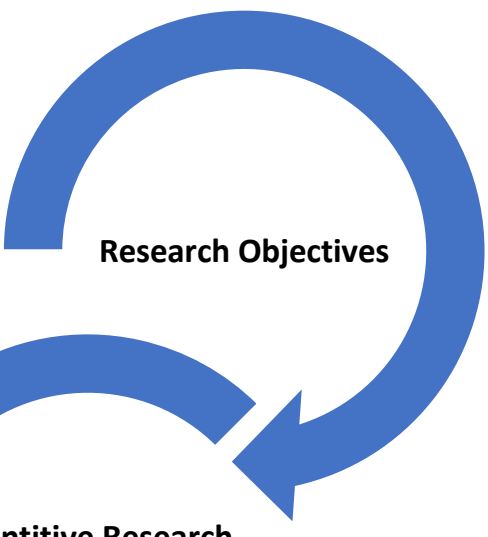

\section{Quantitive Research}

Online Tools: Socialbakers,

Hashtracking, Tweetbinder

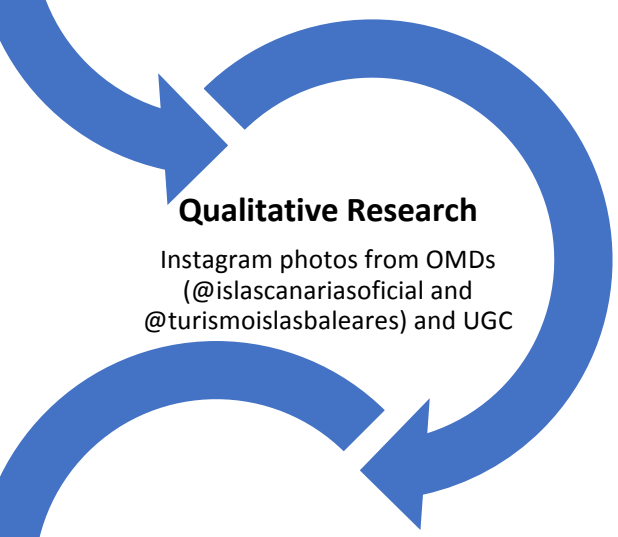

Comparisons.

Conclusions

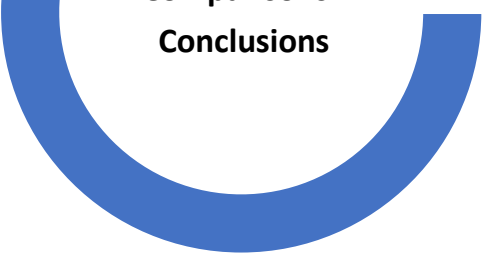

Source: own elaboration 


\section{Analysis and discussion of results}

As we can observe in Table 2, the first thing that draws attention to the content generated by the DMOs of the Canary Islands and the Balearic Islands, is the number of posts generated, whether photographs or videos, during the months July and August 2020. Thus, we see that there are 28 posts (26 photos and 2 videos) for @islascanariasoficial and 51 (29 photos and 22 videos) for @turismoislasbaleares. Therefore, the Balearic Islands stand out in terms of quantity. And in relation to this, it is necessary to note the comparison of the received interactions. In the @islascanariasoficial account we see that its 26 photos received a total of 134,069 likes and 1,353 comments, and with its 2 videos they received a total of 66 comments, 3,022 likes, and were viewed a total of 17,535 times. In the Instagram account of the DMO of @turismoislasbaleares, we perceive that the interactions and responses received on its 29 photos respond to a total of 589 comments and 28,077 likes, and its 22 videos received 196 comments, 6,528 likes and 31,268 views. At first glance it can be seen that the effort of the Balearic Islands in number of contents has been much higher than the Canary Islands, but that the counterpart or result of the Instagram profile of the Balearic Islands, that is, the reaction of its public measured through the number of comments, likes, and number of views, it is much lower than the DMO Instagram profile of the Canary Islands. Perhaps it can be explained by the type of content published by both accounts, while the Canary Islands have managed with their photos published every two days on their landscapes (not only beaches, but also mountains, trails, etc.). In this sense, this profile gathers more interactions in the form of comments and likes, or views, by users than the Balearic Islands that publish almost every day a photo (almost always of beaches) or a video (always promotional). It can be observed that the feelings of the posted content was different, and probably it is even due to the name of the official account, since for the account of the Canary Islands (the choice of @islascanariasoficial) it is more favorable than the name of the account of official DMO`s Instagram account of the Balearic Islands (@turismoislasbaleares) that includes the word "tourism" at the beginning.

In this sense, the image categories were similar and could have been further reduced. Also, we have detected that there was nothing about gastronomy, but clearly the number of publications representing the coast is overwhelming, followed by landscapes, towns, and events. Logically we know that both islands have a traditional claim that link their destination to the concept of sun and beach. Thus, it is a resource that they exploit and link to paradisiacal beaches without people, inducing us to think that they want to evoke the calm, serenity, sustainability, personal experience, respect for nature, etc. In this context, we must remember that these contents and videos on the official DMOs have been created by professional photographers and video producers, which content is fully controlled by the DMOs. We would say that this content responds to the dreamed idea of a beach associated with rest and enjoyment that is what the DMOs wanted to communicate. Thus, in these images we cannot find anything that reminds us we are in the COVID-19 pandemic, and precisely the main idea of the posts on the official accounts could be that the beach is destination to disconnect from this pandemic, assuming that there are sanitary safe spaces, since there are no masses of people that can infect you. 
Table 2

General stats of the management of content by @islascanariasoficial and @turismoislasbaleares (July-August 2020)

\begin{tabular}{|c|c|c|c|c|c|c|c|c|c|c|c|c|c|c|}
\hline \multicolumn{15}{|c|}{ The Canary Islands } \\
\hline \multicolumn{9}{|c|}{ Photo } & \multicolumn{6}{|c|}{ Video } \\
\hline & 苋 & 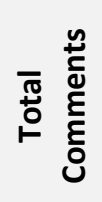 & 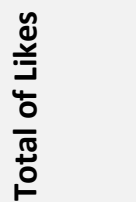 & 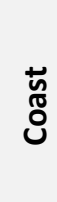 & 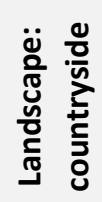 & 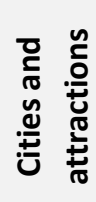 & 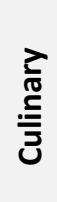 & 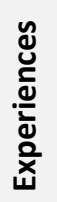 & & 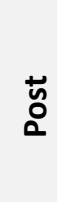 & 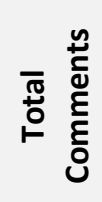 & 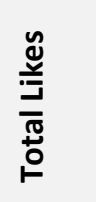 & 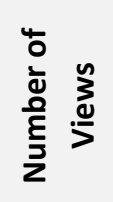 & 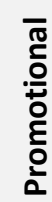 \\
\hline July & 14 & 863 & 78,754 & 10 & 3 & 2 & 0 & 0 & July & 0 & 0 & 0 & 0 & 0 \\
\hline August & 12 & 490 & 55,315 & 8 & 3 & 0 & 0 & 0 & August & 2 & 66 & 3,022 & 17,535 & 2 \\
\hline$\Sigma$ & 26 & 1,353 & 134,069 & 18 & 6 & 2 & 0 & 0 & $\Sigma$ & 2 & 66 & 3,022 & 17,535 & 2 \\
\hline \multicolumn{15}{|c|}{ The Balearic Islands } \\
\hline \multicolumn{9}{|c|}{ Photo } & \multicolumn{6}{|c|}{ Video } \\
\hline & 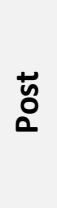 & 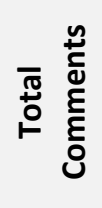 & 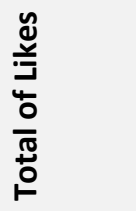 & 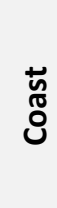 & 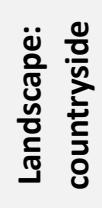 & 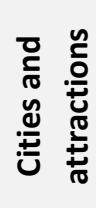 & $\begin{array}{l}\frac{7}{\pi} \\
\frac{.5}{3} \\
J\end{array}$ & 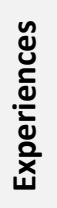 & & 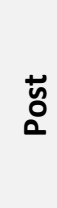 & 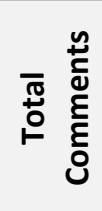 & $\begin{array}{l}\mathscr{D} \\
\stackrel{y}{\Xi} \\
\bar{T} \\
\stackrel{\Xi}{0}\end{array}$ & 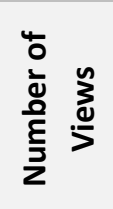 & 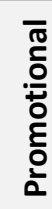 \\
\hline July & 15 & 322 & 16,092 & 15 & 0 & 0 & 0 & 0 & July & 14 & 154 & 4,632 & 18,816 & 14 \\
\hline August & 14 & 267 & 11,985 & 12 & 0 & 1 & 0 & 1 & August & 8 & 42 & 1,896 & 12,542 & 8 \\
\hline$\Sigma$ & 29 & 589 & 28,077 & 27 & 0 & 1 & 0 & 1 & $\Sigma$ & 22 & 196 & 6,528 & 31,268 & 22 \\
\hline
\end{tabular}

Source: own elaboration

Furthermore, the official Instagram account @islascanariasoficial is in Spanish and it has 147 thousand followers, but this DMO has another Instagram account managed in English, called @hellocanaryislands (it has 53.8 thousand followers). Hence, we would like to justify our research only by studying the official account in Spanish due the fact that other official DMO @turismoislasbaleares uses only one account in multiple languages (Spanish, English, French, Italian, German) to promote itself and it has 41.6 thousand followers.

Thus, we found out that the official DMO accounts encouraged tourists to use hashtags with a mention of their destinations. @islascanariasoficial used hashtags directly named to their islands: \#tenerife, \#grancanaria, \#fuerteventura, \#elhierro, \#lagomera, \#lanzarote, \#lapalma, \#lagraciosa, \#islascanarias, but this DMO' s July posts included hashtag slogans like \#theattitudeoflife (in Spanish \#latituddevida) and during August the used hashtag slogans were \#phaseoftranquility" (in Spanish \#phasetranquility) and \#embraceyourislands (in Spanish \#abrazatusislas), with the main idea to create feelings, in the summer affected by the COVID-19, that the Canary Islands represent those hashtag concepts. Also, the official DMO Instagram account @turismoislasbaleares used hashtags of the names of its islands: \#mallorca, \#menorca, \#ibiza, \#formentera, \#islasbaleares; and in English \#mediterranean. During the month of July @turismoislasbaleares launched its promotional video campaign only in Spanish with the following hashtags: \#desiretoreturn and \#desiretoenjoy" (in Spanish \#ganasdevolver, \#ganasdedisfrutar), but in August the promotional video campaign in Spanish was under the hastags, such us 
\#yourTimelsNow and \#TimeForTheBaleariclslands (in Spanish \#tumomentoesahora and \#ahoraislasbaleares). In this manner, these hashtags were added to the same promotional videos in English (previously mentioned), in French (\#LeMomentDesîslesBaléares and \#votreMomentEstMaintenant), in Italian (\#IITuoMomentoéAdesso and \#AdessolsoleBaleari) and in German (\#JetzlstEsSoweit and \#JetztAuzDieBalerean).

Although the official accounts of the DMOs encourage tourists to use previously explained hashtags to refer to their destinations, we have found that UGC did not use those hashtags as much as they were proposed for it. Therefore, we can observe that, when the hashtags are different from the name of the official account of the destinations (in this case the DMOs on Instagram correspond to the hashtags \#islascanariasoficial and \#turismoislasbaleares), they have less impact on the UGC. In this sense, users are less motivated to generate their content using those hashtags, and they use others. In Table 3 we see that the UGC use more a hashtag, such as \#islascanarias or \#canaryislands in the case of the Canary Islands, and the hashtags \#islasbaleares or \#balearicislands for the Balearic Islands, achieving these hashtags a greater reach than the hashtags of the official channels (DMOs).

Table 3

The most popular hashtags related to the Canary Islands and Balearic Islands destinations (July-August 2020).

\begin{tabular}{|c|c|c|c|c|c|c|c|c|}
\hline \multicolumn{5}{|c|}{ The Canary Islands } & \multicolumn{4}{|c|}{ The Balearic Islands } \\
\hline Stats & 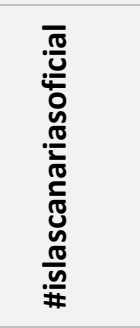 & 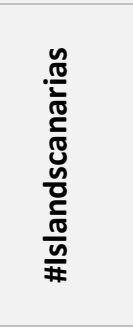 & 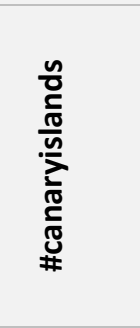 & $\Sigma$ & 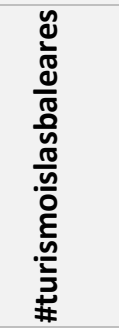 & 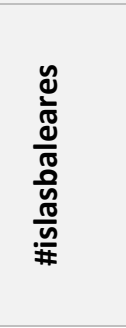 & 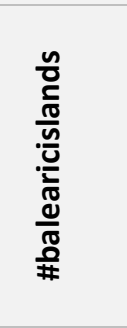 & $\Sigma$ \\
\hline Posts & 1,276 & 11,420 & 10,857 & 23,553 & 110 & 3,112 & 1,984 & 5,206 \\
\hline Users & 634 & 5,845 & 4,956 & 11,435 & 45 & 1,754 & 892 & 2,691 \\
\hline Images & 2,089 & 16,677 & 14,565 & 33,331 & 167 & 4,687 & 2,859 & 7,713 \\
\hline Videos & 103 & 1,033 & 886 & 2,022 & 12 & 165 & 87 & 264 \\
\hline Likes & 154,012 & 328,269 & 288,876 & 771.157 & 31,734 & 89,455 & 57,020 & 178,209 \\
\hline Comments & 2,467 & 29,432 & 26,543 & 58,442 & 767 & 4,324 & 3,987 & 9,078 \\
\hline
\end{tabular}

Source: own elaboration

Thus, if we compare Table 2 and Table 3, we can see how the official DMOs and UGC with all the posts together co-create the image for the analyzed tourist destinations during the summer 2020 when there is a sanitary pandemic. Even thought, the visual images created by the UGC are not as carefully created as those of DMOs, but they give us information about this studied period, because there are people who share their photos with a facemask. But it is true that mostly the content of the images and videos posted by users are referring to the landscape of the islands, frequently referring to the beaches. The Figure 2 shows some examples of photos posted in Instagram by UGC. 
Figure 2

Examples of photos posted in Instagram with hashtag \#turismoislasbaleares by users (UGC) in personal accounts $\left(10^{\text {th }}\right.$ and $12^{\text {nd }}$ July 2020$)$
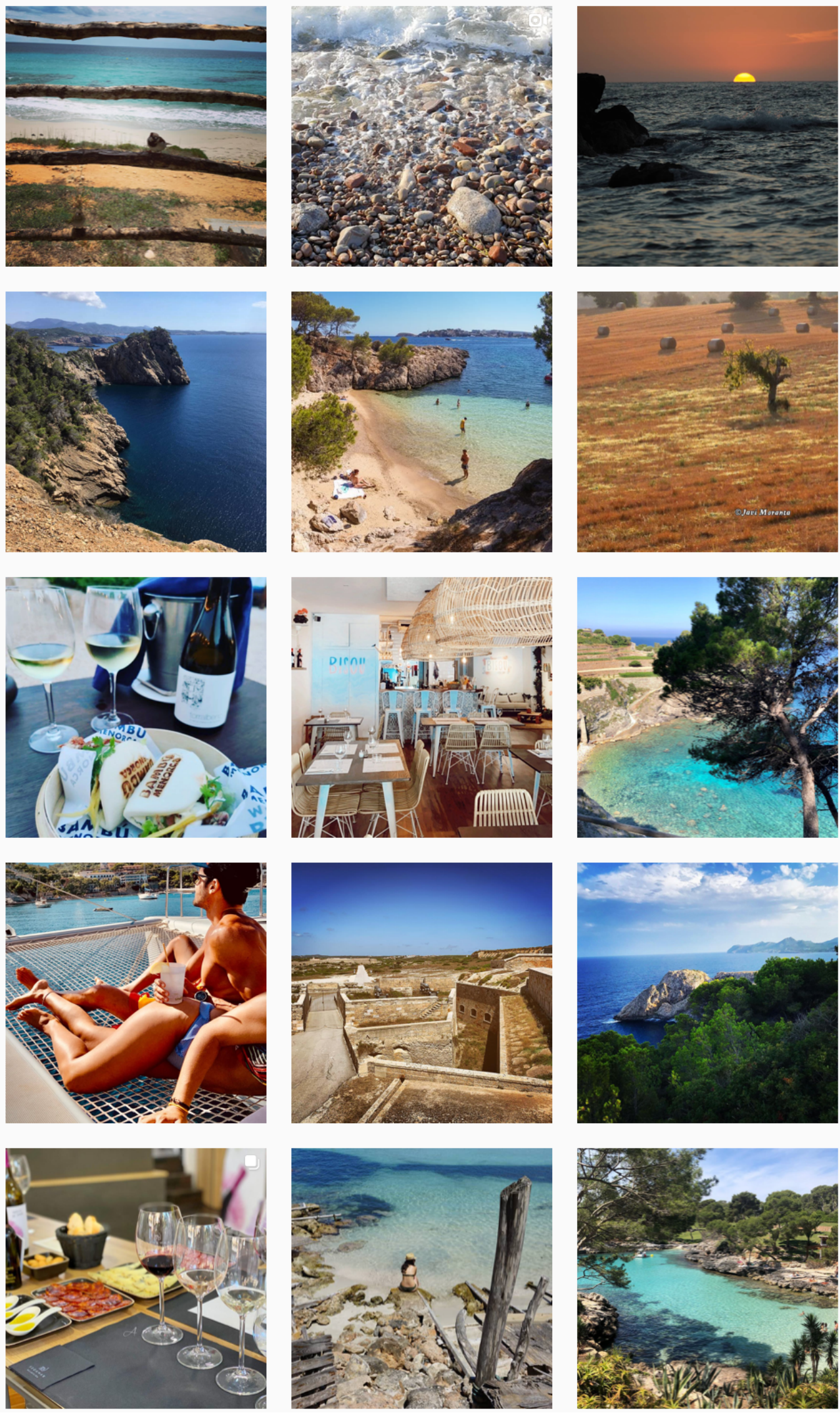

Source: own elaboration 
Regarding the total likes of the UGC posts, they are far from those achieved by the DMOs posts, as well as the comments received. In this sense, the community managers of the official DMOs accounts for the social media strategy and specifically of Instagram, can learn from the users. We insist that the UGC helps to co-create the image of security in a pandemic period, in addition to sustaining and remembering the attractions of the tourist destinations they are enjoying. Therefore, UGC complements with DMOs created image and it gives a touch of realism. The Figure 3 shows an example of the comparison between photos posted by Instagram users (UGC) and the OMD account from the same period.

Figure 3

Comparison between photos posted by Instagram users (UGC) (a) personal account

(b) @turismoislasbaleares official account (July-August 2020)

(a)

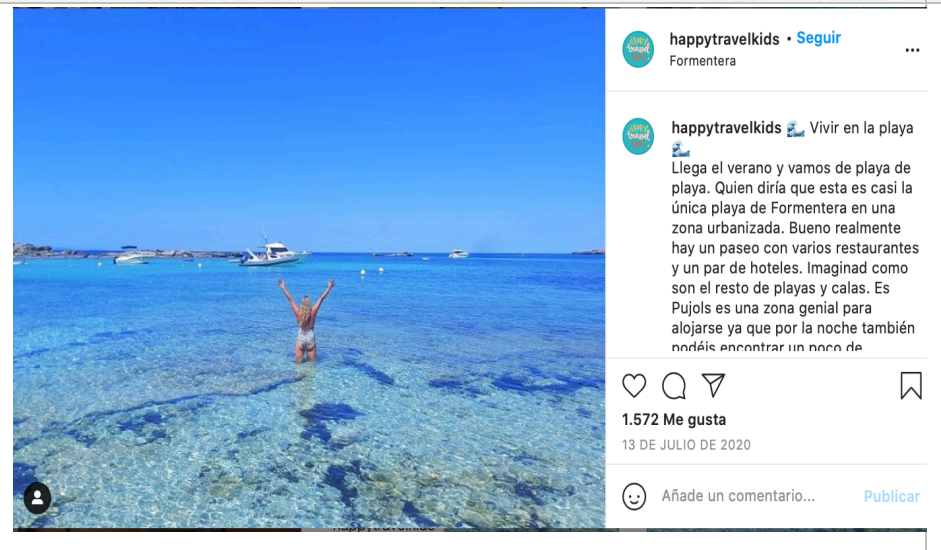

(b)

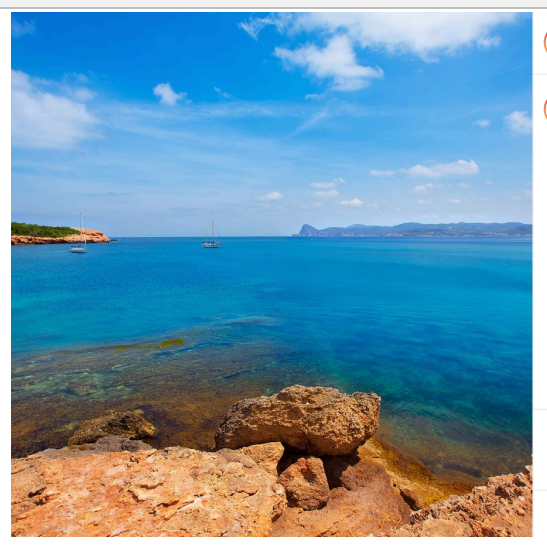

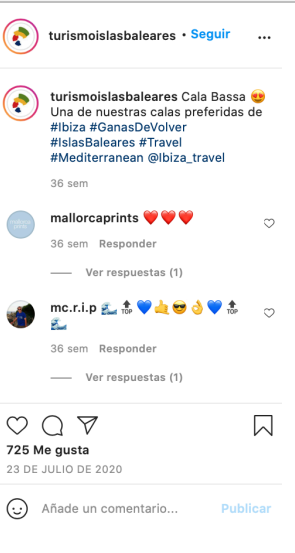

Source: own elaboration

With regards of the publications style of the official DMOs, they are different from the point of view of the written messages. While the posts of @islascanariasoficial address the viewer with questions or phrases that try to awaken emotions and even call for action, we see that the posts of @turismoislasbaleares appeal more to the mere exposure of the name of its beaches and combine it with ads from their advertising campaigns. So, @turismoislasbaleares loses the possibility of interaction with the users. Also, we would like to add that both accounts of the DMOs in all the posts use an emoji. The Figure 4 shows some examples of the style of the official posts of the DMOs @islascanariasoficial and @turismoislasbaleares profiles.

Figure 4

Examples of posts by @turismoislasbaleares and @islascanariasoficial (July-August 2020)

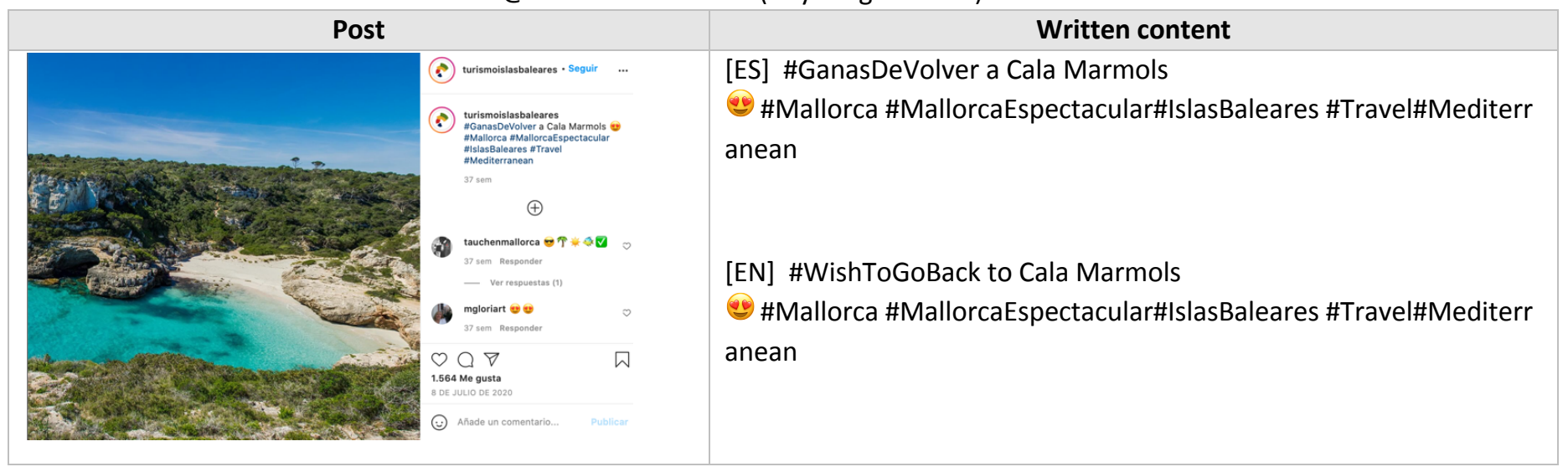




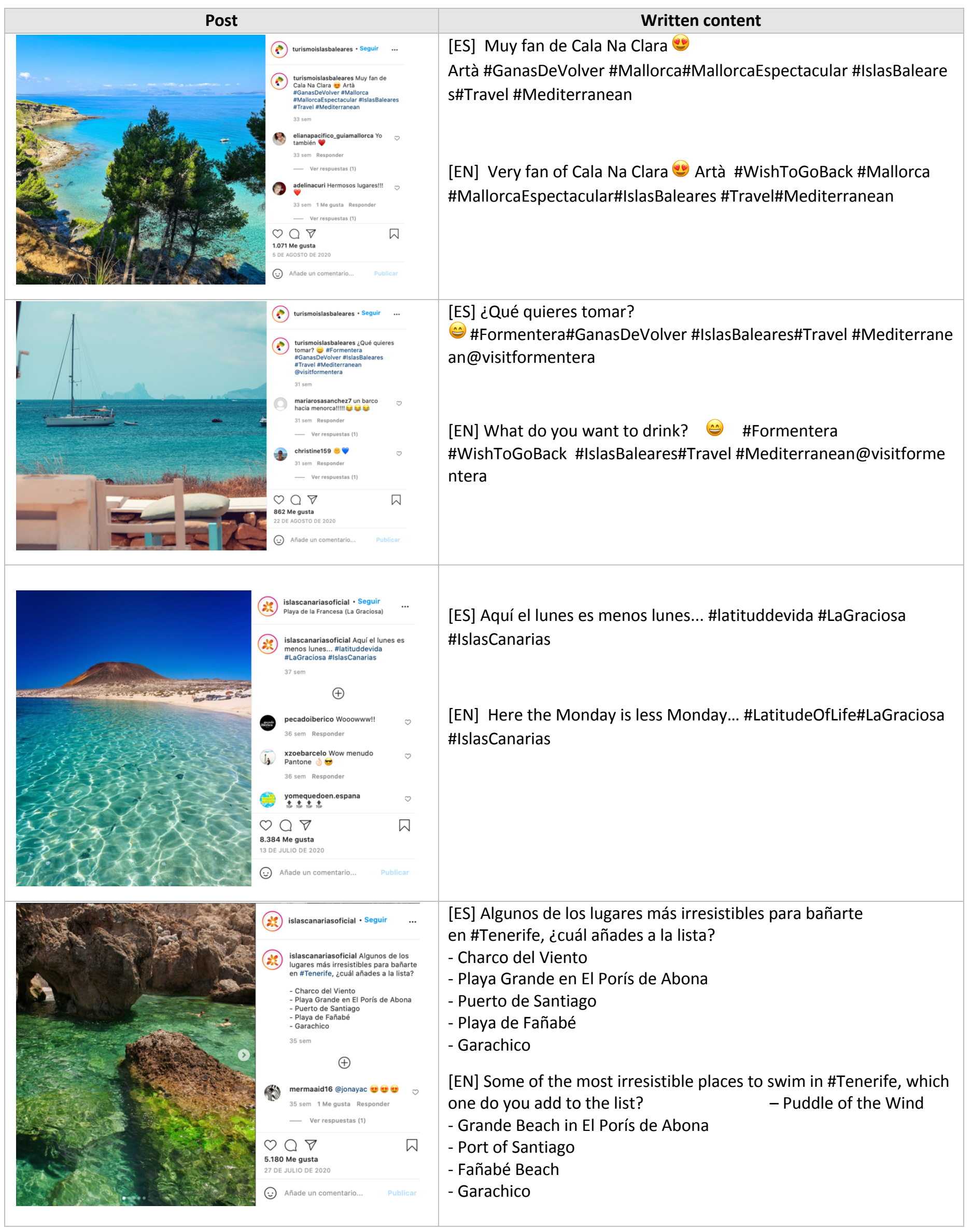




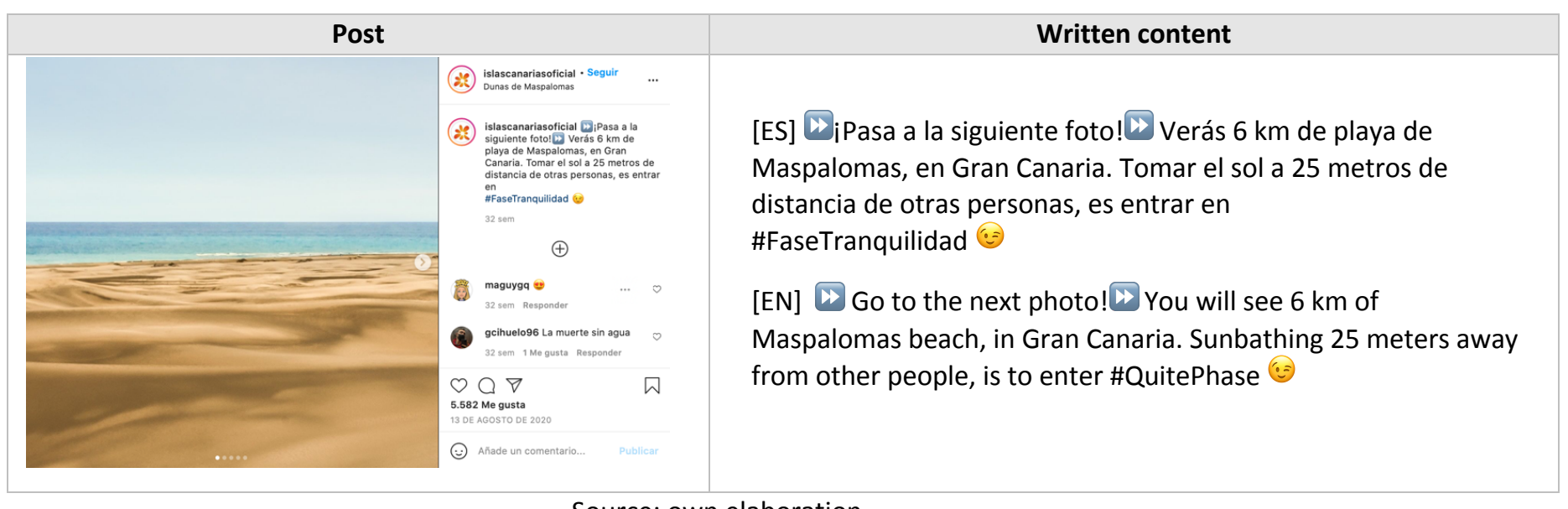

Source: own elaboration

Concerning the content created by Instagram users, it is remarkable that the accounts that generated the most engagement were not the official accounts, but of user accounts of private people. Majority these images respond to moments that have passed on the beach or moments of enjoying in a friends' company, although there were images of posing, or with food or drink, and of course, there were also images with people wearing a facemask as expected for that studied research period.

\section{Conclusions and practical implications}

According to various authors mentioned in the literature review of this research paper, with the obtained results from the applied content analysis technique, we can conclude that Instagram platform, with its particular characteristics of visual appeal and possibilities to leave hashtags, is one of the best online tools to create and recreate tourism destination image in times of some kind of uncertainty, like pandemic caused by COVID-19 or in a stable tourism season. Hence, the use of Instagram platform for image creation of tourism destination is like a two-edged sword: from one side the image can be perfectly managed from the marketing strategy point of view created by the official tourist DMO and other is conformation or confrontation of user-generated content (UGC) related to the particular tourism destination. As it worked in the $20^{\text {th }}$ century until arrival of Web.2.0, DMO with help of marketing companies have been creating "ideal image" of its tourist destination by managing all the possibilities to eliminate any negative aspect. But as we can see, in an age of information transparency thanks to the social networks, image creation only in hands of $\mathrm{DMO}$ is the $20^{\text {th }}$ century relict. Therefore, every time more the "crowd" or UGC online plays bigger role in formation of tourism destination image, or we could say that its shifting to the other part of the sword. In this sense, added UGC gives informative credibility and believability of the created image as it is confirmed by many different independent tourists (or we could call them as the real ambassadors or messengers) that only voluntary without any commercial interest share their experiences on Instagram. Hence, we can confirm that both players (DMO and UGC) make value co-creation or synergy for the image of tourism destination and, therefore, Instagram platform is connecting key point for meeting of these two players.

In this context, we would suggest different public and private destination management organizations (DMO) use different social media platforms and specially Instagram for the image creation or its improvement. It is important and effective to use promotional photos and videos by representing the beauty, serenity and attractiveness of the tourism destination, but at the same time, it is important express the real situation if there is any security challenge and how it is managed by the DMO or/and local authorities and community. Therefore, because of the specific characteristics of Instagram platform, use of hashtags as an efficient way to communicate in a written language, it is vital for the tourism DMOs to use slogan hashtags that create emotional bonding and attachment to the destination and not so much pure informative slogans. Consequently, promotional messages 
on Instagram which have aroused emotional closeness to the destination, online users are far more willing to share them with other users.

\section{Bibliographic references}

Araújo, S. (2019). Instagram ya tiene 800 millones de usuarios activos, 100 millones más desde abril. Genbeta.com. Available on: https://www.genbeta.com/redes-sociales-y-comunidades/instagram-ya-tiene800-millones-de-usuarios-activos-100-millones-mas-desde-abril Accessed: November 2020.

Babbie, E. (2014). The basics of social research, 6th ed. Wadsworth: Cengage Learning.

Bigné, E. (2018). “Marca Turística: ¿Quién marca a quién?” in Cervera A. y Pastor J. M (eds.) (2018). Valencia y su economía. Un modelo sostenible es posible. Universitat de Valencia.

Bigné-Alcañiz, E., Sánchez García, I., and Sanz Blas, S. (2005). Relationships among residents' image, evaluation of the stay and post-purchase behaviour. Journal of Vacation Marketing, 11(4), 291-302.

Brey, E. T. (2019). Co-creating Value from Social Media: A Framework. Journal of Creating Value, 5 (2), 222-236. https://doi.org/10.1177/2394964319869054

Frías Jamilena, D. M., Polo Peña, A. I., Chica Olmo, J., \& Cano Guervos, R. (2017). Influencia del contexto del turista en el CBDBE. Una aplicación empírica del efecto que otros turistas de su entorno geográfico ejercen en la valoración del CBDBE. In XXIX Congreso de Marketing AEMARK (2017), p 1251-1266. ESIC.

García Haro, M. A. (2018). La co-creación de valor a través de las redes sociales: efecto en la imagen de Cuenca como destino turístico. Tesis de Doctorado, Universidad de Castilla-La Mancha, Ciudad Real.

González, R. (2012). “Marcas turísticas: algunas reflexiones”, Hosteltur. Available on: https://www.hosteltur.com/194010_marcas-turisticas-algunas-reflexiones.html Accessed: November 2020.

Grönroos, C. (2020). 17 Co-creation of Value in Service. The Routledge Companion to Strategic Marketing, 261.

Grönroos, C. (2017). On Value and Value Creation in Service: A Management Perspective. Journal of Creating Value, 3 (2), 125-141, https://doi.org/10.1177/2394964317727196

Hanan, H. and Putit, N. (2014). Express marketing of tourism destinations using Instagram in social media networking. Hospitality and Tourism: Synergizing Creativity and Innovation in Research. Taylor \& Francis Group: London, UK, 471-474.

Hunt, J. D. (1975). Image as a Factor in Tourism Development. Journal of Travel Research, Volume 13 Issue 3, 17.

Iglesias-Sánchez, P. P., Correia, M. B., Jambrino-Maldonado, C., and de las Heras-Pedrosa, C. (2020). Instagram as a Co-Creation Space for Tourist Destination Image-Building: Algarve and Costa del Sol Case Studies. Sustainability, 12 (7), 2793. https://doi.org/10.3390/su12072793

Kim, H., \& Stepchenkova, S. (2015). Effect of tourist photographs on attitudes towards destination: Manifest and latent content. Tourism Management, 49, 29-41.

Költringer, C. y Dickinger, A. (2015). Análisis de imagen y marca de destino de fuentes en línea: un enfoque de minería de contenido web. Revista de investigación empresarial, 68 (9), 1836-1843. 
Law, R., Buhalis, D. and Cobanoglu, C. (2014). Progress on information and communication technologies in hospitality and tourism. International Journal of Contemporary Hospitality Management, 26 (5), 727-750. https://doi.org/10.1108/IJCHM-08-2013-0367

Ministerio de Industria, Comercio y Turismo (2020). Mincotur.gob.es. Available on: https://www.mincotur.gob.es/es-es/Paginas/index.aspx. Accessed: November 2020.

Munar, A. M. (2011). Tourist-created content: Rethinking destination branding. Int. J. Cult. Tour. Hosp. Res, 5, 291-305.

Nixon, L.; Popova, A. and Önder, I. (2017). How Instagram influences visual destination image: A case study of Jordan and Costa Rica. In Proceedings of the eTourism Conference (ENTER2017), Rome, Italy, 24-26 January.

Park, J. and Oh, I. K. (2012). A case study of social media marketing by travel agency: The salience of social media marketing in the tourism industry. International Journal of Tourism Sciences, 12 (1), 93-106.

Ramaswamy, V. (2009). Co-creation of value-towards an expanded paradigm of value creation. Marketing Review St. Gallen, 26(6), 11-17.

Royce A. Singleton, Jr. and Bruce C. Straits, (2010). Approaches to social research, 5th ed. New York: Oxford University Press.

Sarmiento-Guede, J. R. and Ferrao, A. J. (2019). La e-experiencia de marca a través de los medios sociales y su influencia en la e-calidad de la relación y la e-fidelización. Análisis empírico en los sitios web de viajes. Cuadernos de Turismo, 44, 351-380.

Sarmiento-Guede, J.R., and Rodríguez Terceño, J. (2020). La comunicación visual en Instagram: estudio de los efectos de los micro-influencers en el comportamiento de sus seguidores. Estudios sobre el mensaje periodístico, 26(3), 1205-1216.

Sarmiento-Guede, J. R., Curiel, J. D. E., and Antonovica, A. (2021). Aumento de la influencia de los vídeo bloggers de viaje mediante el uso de Youtube para vender viajes indirectamente a través de marketing de relaciones y la calidad del servicio en línea. Management Letters/Cuadernos de Gestión, 21(1).

Sorensen, A., Andrews, L., and Drennan, J. (2017). Using social media posts as resources for engaging in value co-creation. Journal of Service Theory and Practice, 27 (4), 898-922.

Tankovska, H. (2021). Global social networks ranked by number of users 2021. Statista. Available on: https://www.statista.com/statistics/272014/global-social-networks-ranked-by-number-of-users/. Accessed: April 2021.

Veal, A. J. (1997). Research methods for leisure and tourism. A practical guide, 2nd ed. Harlow: Pearson Education.

Walter, E. and Gioglio, J. (2014). The power of visual storytelling. New York: McGraw-Hill Education.

Weber, R. P. (1990). Basic content analysis, 2nd ed. London: Sage University Paper.

Esta obra está bajo una Licencia Creative Commons

Attribución-NoCommercial 4.0 International

(c) EY-NC 